\title{
College English Teaching Status and Individualized Teaching Design in The Context of Mobile Learning
}

\author{
https://doi.org/10.3991/ijet.v14i12.10704 \\ Yuan Zhang $(\bowtie)$ \\ Jingdezhen Ceramic Institute, Jingdezhen, China \\ zhangyuan@jci.edu.cn \\ Lu Zuo \\ Henan University of Chinese Medicine, Zhengzhou, China
}

\begin{abstract}
This paper aims to optimize the design of individualized classroom teaching for mobile English learning in colleges, and find a scientific and effective English teaching mode and strategy for mobile learning. For this purpose, the application and evolution of mobile learning in English teaching was investigated, and the concept and theoretical bases of mobile learning were introduced in details. Through literature review, questionnaire survey and face-toface interview, the status of mobile English learning among college students was analysed qualitatively and quantitatively from three dimensions, namely, the mobile device, learning resource and learning attitude. Then, several strategies for individualized teaching reform were presented through status analysis. Finally, the application of individualized mobile English learning was demonstrated through case studies on public platforms like Weibo and WeChat. The research findings shed new light on the individualized English learning among college students and lay a scientific basis for the application of mobile learning in college English education.
\end{abstract}

Keywords-Mobile learning, English teaching, questionnaire, individualized teaching, countermeasures.

\section{$1 \quad$ Introduction}

With the deepening of global integration, English has become an important tool for information exchange in various fields between different countries. The proficiency of the language is now a yardstick of the quality of international exchange talents [1]. In China, the classroom teaching mode has been adopted by most universities for English education. However, this teaching mode fails to provide desirable results, because it cannot teach the students according to their aptitude and provides little chance for learners to practice the language [2]. To solve the problem, the Chinese Ministry of Education has encouraged universities to promote individualized and autonomous English learning. 
These two learning methods need to be promoted based on the latest trend of learning, that is, mobile learning. As a type of autonomous and assistive learning, mobile learning is enjoying a solid hardware and software foundation, thanks to the development of computer technology, communication technology and mobile equipment. Since its introduction to China in 2000, mobile learning has been extensively studied from various perspectives. Some scholars explained this concept in light of distance education and considered it as the main direction of future learning [3]. Some scholars designed the learning activity framework based on mobile learning after exploring the demand, learners, scenarios, technology environment and supporting services of this learning mode. However, the domestic studies on mobile learning have emphasized the basic theories over the classroom design, technology development and actual application of mobile learning [4].

In view of the above, this paper reviews the application of mobile learning in college English teaching and proposes relevant improvement strategies, aiming to enhance the effect of college English teaching. Specifically, the relevant concepts and learning theories were introduced in details. Through literature review, questionnaire survey and face-to-face interview, the status of mobile English learning among college students was analysed qualitatively and quantitatively from three dimensions, namely, the mobile device, learning resource and learning attitude. Then, the existing problems were identified, and their causes were fully discussed. On this basis, improvement strategies were put forward considering the software/hardware technology demand, English teachers, college students, mobile learning system and mobile learning resources [5]. Next, the application of mobile English learning was demonstrated through case studies on public platforms like Weibo and WeChat. The research findings shed new light on the individualized English learning among college students and lay a scientific basis for the application of mobile learning in college English education.

\section{Theoretical Bases of Mobile learning}

\subsection{Definition and development}

Definition: Mobile learning is a learning mode that can be carried out at any time and any place with the aid of mobile computing devices. These devices must effectively present the learning contents and support the two-way communication between the teacher and the learner. Whenever he/she is willing to learn, the learner should be able to acquire online resources and communicate with others through unlimited mobile network and mobile electronic devices [6]. Mobile learning mainly features personalization, interactivity, ubiquity and immediacy. The learning tools include mobile phones, personal computers, tablet computers and electronic dictionaries.

Development: The concept of mobile learning was proposed by Stanford University. In 2000, Stanford Learning Lab designed an experiment to learn Spanish on mobile phones. The experiment covers the exercises, tests, queries, translation and storage of new words. The results show that mobile phones can promote the review and 
exercise performance, although it is not suitable for learning new knowledge [7]. When the mobile network was not yet popularized, mobile learning via SMS and WAP websites has been proved as a positive effect on listening, vocabulary, grammar and writing. With the rapid development of mobile networks and mobile devices, the hardware/software foundation of mobile learning has been consolidated. The relevant infrastructure supports various modes of English learning, such as audio learning, video learning, image learning and text learning. The latest modes include mobile dictionary, public English learning platform and English learning applications.

\subsection{Theoretical bases}

Table 1 lists some of the leading theories on mobile learning.

Table 1. Theories on mobile learning

\begin{tabular}{|l|l|}
\hline \multicolumn{1}{|c|}{ Name } & \multicolumn{1}{c|}{ Description } \\
\hline Informal learning & $\begin{array}{l}\text { Unlike formal learning, informal learning is an implicit mode of learning, that can be } \\
\text { carried out at any time and any place. }\end{array}$ \\
\hline Situated cognition & $\begin{array}{l}\text { Learning is regarded as a self-construction activity through the interaction with the } \\
\text { environment and other learners. }\end{array}$ \\
\hline Blended learning & $\begin{array}{l}\text { This is a formal education program in which a student learns at least in part through } \\
\text { delivery of content and instruction via digital and online media with some element of } \\
\text { student control over time, place, path, or pace. Face-to-face classroom methods are } \\
\text { combined with computer-mediated activities. }\end{array}$ \\
\hline Contextual learning & $\begin{array}{l}\text { Learning takes place when teachers are able to present information in a way that } \\
\text { students are able to construct meaning based on their own experiences. }\end{array}$ \\
\hline Constructivism & $\begin{array}{l}\text { This is a learning theory which sees learning as a process in which the learner active- } \\
\text { ly constructs or builds new ideas or concepts based upon current and past knowledge } \\
\text { or experience. }\end{array}$ \\
\hline
\end{tabular}

Mobile learning is an informal learning mode that satisfies the requirements of contextual learning, blended learning and situated cognition. It attaches equal importance to the autonomy of the learner and the guidance of the teacher. Besides, mobile learning highlights the autonomy and enthusiasm of students in learning. The theories on mobile learning lays the basis for the design of an individualized mode for mobile learning. Following different theories, the English classroom teaching can be individualized [8]. The personalized and convenient learning mode of mobile learning makes it possible to learn languages at any time and any place.

\section{Status Survey and Results Analysis}

The status survey was carried out to draw a panorama of the mobile learning situation among Chinese college students, find out the existing problems, and develop countermeasures. A questionnaire was designed for the survey based on the principle of objectivity, authenticity and scientificity. The questions mainly target three aspects: mobile device, learning resource and learning attitude [9]. 
A total of 300 questionnaires were issued to college students, among which 283 (94.3\%) were returned. According to the answers, males and females respectively account for $52.3 \%$ and $47.7 \%$ of the respondents, while liberal arts students and science students respectively take up $51.6 \%$ and $48.4 \%$. Overall, the respondents were evenly distributed in terms of gender and majors, indicating that the survey results are authentic and reliable.

\subsection{Results analysis}

Mobile deice: Mobile phone is the most popular mobile device among the respondents. Every respondent owns a mobile phone, or rather, a smart phone. Mobile phones have dominated the life, communication and entertainment of college students, due to the reduction in the cost of phone and communication [10]. The survey also shows that $95 \%$ of the respondents have personal computers and $45 \%$ have tablet computers. The results indicate that, from the angle of hardware, the mobile devices owned by college students can meet the requirements for various forms of mobile learning.

Learning resource: Table 2 shows the answers to the question whether the proliferation of wireless networks has helped college students acquire online learning resources.

Table 2. Utilization of online resources by college students in mobile learning

\begin{tabular}{|l|c|}
\hline \multicolumn{1}{|c|}{ Description } & Percentage \\
\hline The resources cannot be accessed rapidly. & $10 \%$ \\
\hline There are few resources available. & $5 \%$ \\
\hline There are few useful ones among the abundant resources. & $18 \%$ \\
\hline There is no way to find the abundant resources. & $47 \%$ \\
\hline There are abundant resources that help English learning. & $20 \%$ \\
\hline
\end{tabular}

Learning resource types
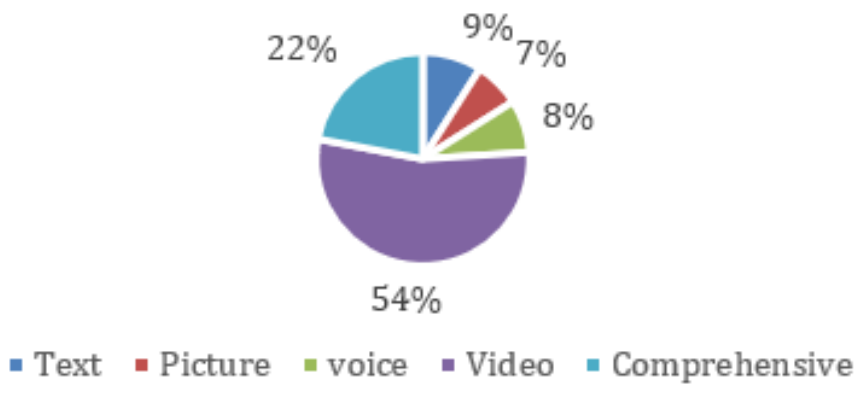

Fig. 1. Learning resources preferred by the respondents 
As shown in Table 2, fewer than 5\% of the respondents complained about the lack of learning resources; $55 \%$ knew there are many learning resources available, but could not find the suitable ones or useful ones; only $20 \%$ recognized the abundance of learning resources and made rational use of them in English learning [11]. Figure 1 shows the learning resources preferred by the respondents.

As shown in Figure 1, it is clear that the most favourite learning resource among college students is video. The video, as an integration of audios and images, creates an immersive learning environment, making English learning vivid and interesting. Such an environment can arouse the interests of the learner and enable them to stay focused [12]. Besides, the comprehensive mode is also welcomed by the students, with $22 \%$ of the respondents taking it as the preferred learning mode. The text $(9 \%)$, image $(7 \%)$ and audio (8\%) are much less popular.

Learning attitude: The survey shows that most college students keep a positive attitude towards mobile English learning. More than $70 \%$ of the respondents believe that mobile learning is so convenient that they can learn English anytime, anywhere; over 50\% hold that mobile learning can enhance their autonomy and effect of learning; those who claim mobile learning has no effect or a negative effect only take up $4 \%$ and $5 \%$, respectively, of all the respondents. The statistical results are shown in Table 3.

Table 3. Attitude towards mobile learning

\begin{tabular}{|l|c|}
\hline \multicolumn{1}{|c|}{ Description } & Percentage \\
\hline Clarify learning objectives. & $13 \%$ \\
\hline Strengthen learning effect. & $30 \%$ \\
\hline Enhance learning autonomy. & $34 \%$ \\
\hline Resolve questions timely. & $39 \%$ \\
\hline Support ubiquitous learning. & $73 \%$ \\
\hline Have no effect. & $4 \%$ \\
\hline Reduce learning efficiency. & $5 \%$ \\
\hline
\end{tabular}

Note that only $13 \%$ of the respondents believe that mobile English learning can clarify the learning objectives. This indirectly reveals that college students need specific plan and goals in mobile learning. It is necessary to provide guidance to them on learning skills and strategies [13].

Figure 2 presents the number of respondents who find mobile learning helpful to English reading, speaking, listening, writing, vocabulary, grammar, and learning background.

As can be seen from Figure 2, the $72 \%$ of college students find mobile learning helpful to English listening, and 52\% find it helpful to speaking. The positive impacts on listening and speaking are attributable to the favourable linguistic environment created by multimedia technologies of mobile learning. Since it can be conducted at any time, mobile learning exerts a positive effect on vocabulary. Reading and learning background are also promoted by mobile learning, because students are enabled to look for learning resources on online platforms. By contrast, only $18 \%$ and $14 \%$ stu- 
dents agree that mobile learning helps writing and grammar. This is because the attention of the learner is not concentrated in mobile learning.

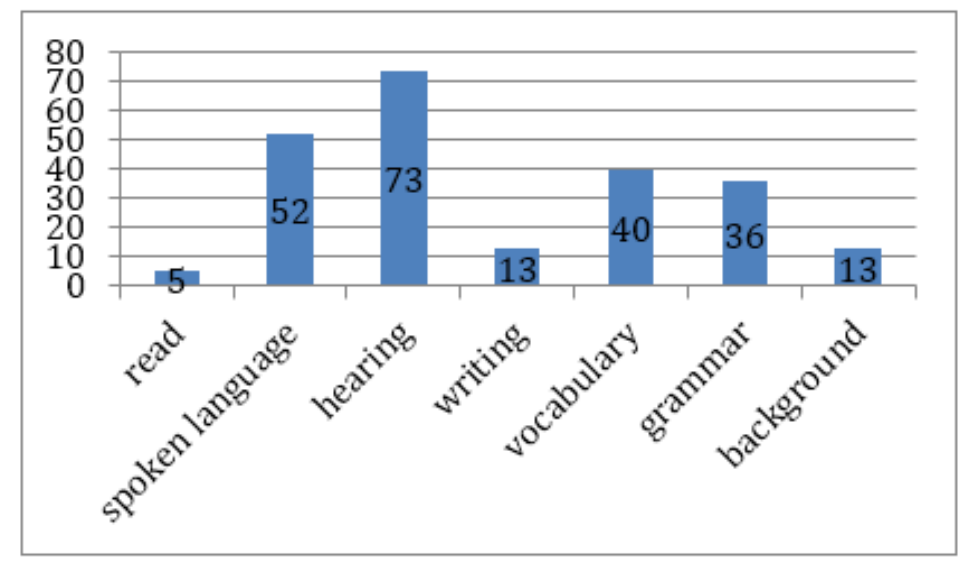

Fig. 2. Effects of mobile English learning

\subsection{Interview results and cause analysis}

Interview results: Most college students being interviewed report that they are easily disturbed in mobile learning and have difficulty to stay focused. These problems must be considered in the design of mobile learning and teaching. Since English learning requires long-term practice, the learning effect hinges on the time spent on mobile English learning. The interview shows only a small portion of college students engage in long-term learning using mobile devices. Thus, English teachers must encourage students to learn on mobile devices over mobile network. Moreover, different college students devote different lengths of time to mobile learning. According to the study of Stanford University Lab, college students are recommended to control the mobile learning within $1 \mathrm{~h} \mathrm{[14].}$

Cause analysis: The learner always longs to acquire knowledge and communicate with others anytime, anyplace. To fulfil their desires, mobile learning has to rely on the wireless Internet access of mobile devices. The effect of mobile learning is mainly constrained by the wireless network. The more popular the wireless network, the more widely accepted the mobile learning. As a new learning mode, mobile learning differs greatly from the traditional classroom teaching. College students should learn more about the learning mode, improve their self-control, and enhance their efficiency and interests of mobile learning under the proper guidance of English teachers [15-22]. 


\section{Mobile Learning Teaching Design and Application}

\subsection{Optimization strategies for mobile learning design}

Creating good software/hardware conditions for mobile learning: The hardware is fundamental to the implementation of mobile English learning. It is a prerequisite and basic guarantee for mobile learning. Colleges should cooperative with governments and enterprises to promote the development of campus networks, laying the basis for a high-quality wireless system of mobile learning.

The software condition refers to the human-computer interaction interface and the diverse mobile learning software that can arouse the interests of students. More mobile learning software should be developed, with the aim to offer students more options and enhance university-enterprise cooperation.

Reforming the teaching mode of college English teachers: As the organizer and supervisor of teaching activities, teachers play an important role in mobile learning. To solve the problems in mobile learning, college English teachers need to reform their teaching model.

1. Teaching-oriented mobile English teaching mode: In the teaching-oriented mobile English teaching mode, teachers guide students in mobile learning by selecting teaching objectives and contents. The following are the major components of this mode: reception learning and advance organizer teaching; five-step learning; ninestep teaching; mastery learning; situational immersive teaching; demonstrationimitation teaching.

2. Learning-oriented mobile English teaching mode: In the learning-oriented mobile English teaching mode, the students choose the learning objectives and contents independently to realize individualized and autonomous learning.

3. Competitive mobile English learning mode: In the competitive mobile English learning mode, the students' learning enthusiasm is aroused by stimulating their competitive spirit. Many studies have shown that people are more efficient than usual when their brains are in the competition mode. Here, the competitive teaching strategy is introduced to mobile English learning to cultivate talents in an innovative way. This mode is generally based on questions, group cooperation or quick response.

Mobile learning strategies for college students: College students must attach importance to mobile English learning, and grasp and practice necessary methods and strategies.

1. Time management: The time spent on mobile learning is discrete and vulnerable to external interference. The students should manage their learning time effectively, prepare learning plans, and spend enough time on mobile learning each day.

2. Task division: In mobile learning, college students should split a complex task into several small goals that can be achieved through easy steps. By completing these small goals, the college students can improve their self-efficacy and have more interest in learning. Taking the reading of a 400-word article for example, a college 
student can read the article part by part when they are on the bus or on the bed. In this way, the reading task becomes easier to complete and the learning effect is improved.

3. Tool utilization: College students should fully utilize learning software and tools to seek online help and collaborative learning. For instance, they can improve the effect of mobile learning with the remote assistance from English-speaking users.

4. Resource search: The use of online learning resources is the key to mobile learning. To increase the learning efficiency, college students should know how to find learning resources with mobile devices and make effective management of these resources.

\subsection{Individualized teaching design for mobile learning and its application}

Individualized teaching design for mobile learning: Individualization and autonomy are two focal points in mobile learning. The two learning modes help the students make overall progress in many areas, including listening, speaking, vocabulary, reading, grammar, testing, answering questions and tool utilization. According to relevant learning theories, the learning resources and methods for mobile learning need to be modularized. Figure 3 shows the logic diagram of modular learning of English words.

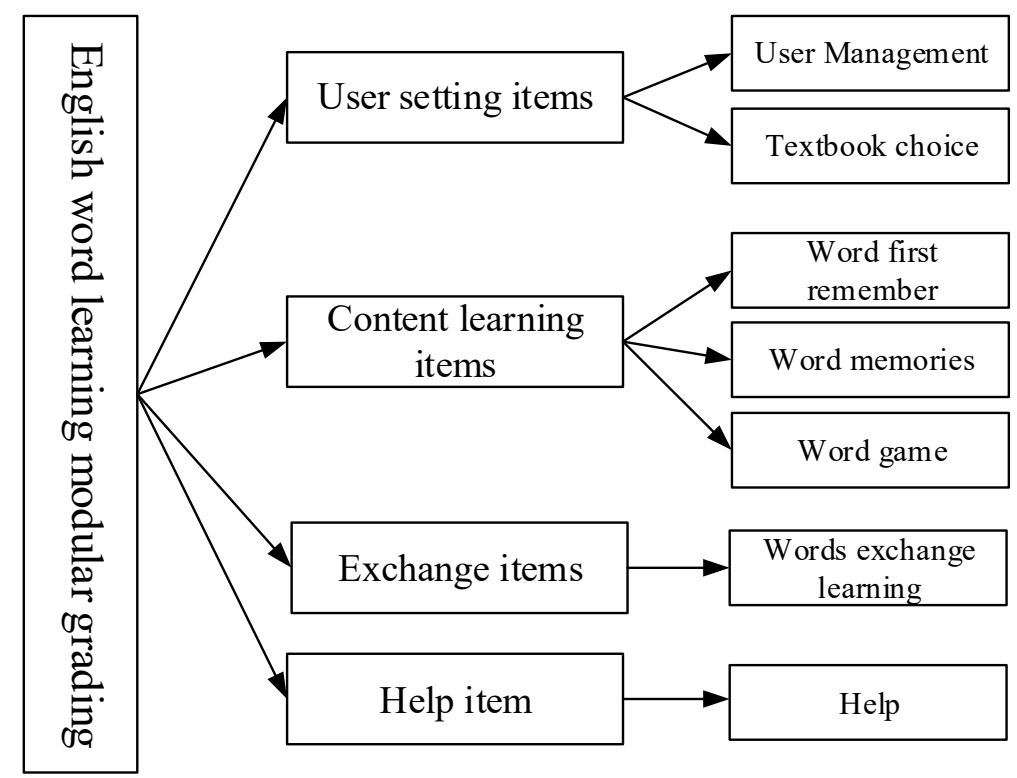

Fig. 3. Logic diagram of modular learning of English words

The mobile teaching design pursues conciseness and effectiveness. Based on the modular idea, each knowledge point is encapsulated into a knowledge module that can be learned easily. As a new teaching method, mobile learning has a certain appeal for 
young people. In the teaching design, more videos and multimedia resources should be incorporated to cater to the interests of college students.

Mobile learning application based on Weibo and WeChat public account: Weibo, China's equivalent of Twitter, is a relationship-based information acquisition, sharing and dissemination system. It can be used online or on electronic terminals. An ordinary user is allowed to post a message with fewer than 140 characters, update his/her Weibo account at any time, and share text, image, audio, video and links instantly.

The WeChat public accounts are normally owned by the fans or experts in a specific field. The owners can attract ordinary WeChat users by publishing contents on their accounts, while the users can learn the knowledge they need from these accounts.

Both Weibo and WeChat public account offer convenient platforms for mobile learning. These platforms support simple operation, real-time publishing and classified management. The learning contents on these platforms can include teaching courseware, learning methods, learning points, and homework. Figure 4 is a screenshot of a WeChat public account for English learning.

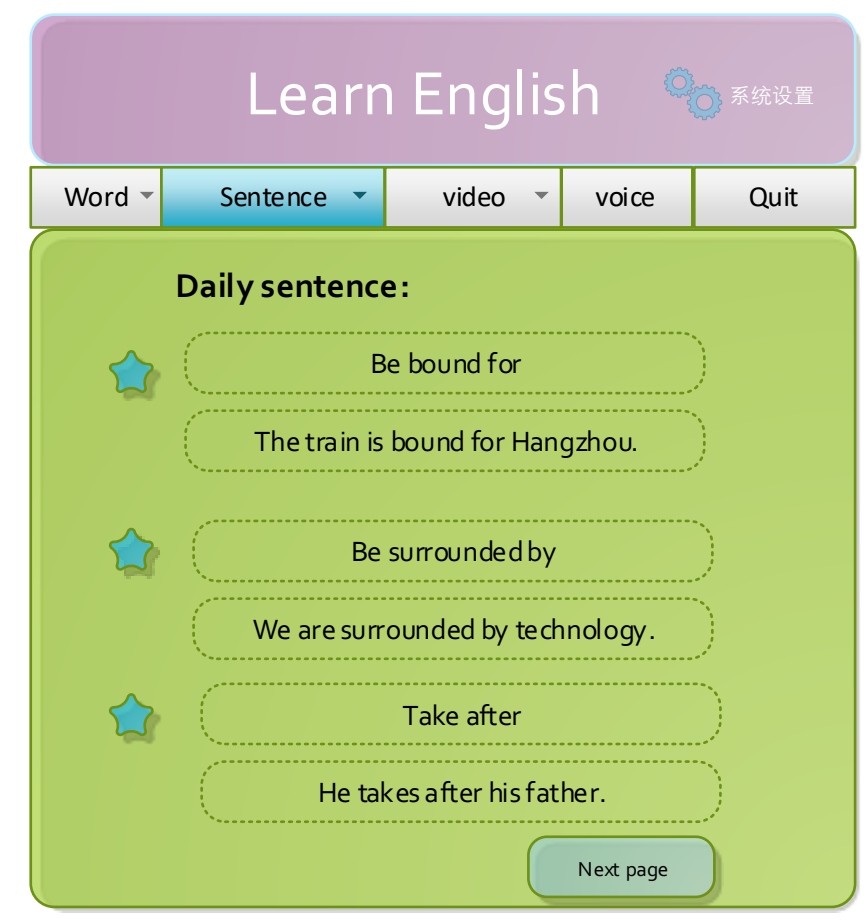

Fig. 4. The screenshot of a WeChat public account for English learning.

The diversified modes of mobile learning enable college students to learn knowledge anytime and anywhere, and provide them with a new way to improve their English proficiency. 


\section{Conclusion}

In the information age, mobile learning has attracted more and more attention as a novel way of learning. Against this backdrop, it is very meaningful to analyse the status of mobile English learning in Chinese colleges, and put forward improvement measures and an individualized teaching design. Considering the theoretical bases of mobile learning, this paper investigates the status of mobile English teaching from such three dimensions as learning device, learning resource and learning attitude through questionnaire survey and interview. On this basis, a teaching design for mobile learning was prepared and applied in actual environments. The following conclusions were drawn from the above research.

1. At present, Chinese college students face several problems in mobile learning, including difficulty to stay focused, irrational spending of learning time and unclear learning objectives. The mobile learning efficiency needs to be improved with a rational design of the teaching contents, objectives and time.

2. Meaningful instructions were presented for individualized mobile teaching through the analysis on the teacher, the learner, the learn strategies and the learning resources.

3. The research findings are of guiding significance for the informatization of college English teaching and the learning autonomy and self-efficacy of college students.

\section{References}

[1] Rothman, A. I., Cusimano, M. (2001). Assessment of english proficiency in international medical graduates by physician examiners and standardized patients, Medical Education, 35(8): 762-762. https://doi.org/10.1046/j.1365-2923.2001.00964.x

[2] Chen, H., Chen, H. (2015). The influence of world englishes on chinese english and english teaching in college, Journal of Organometallic Chemistry, 192(1): 1-15. https://doi.org/10.1016/S0022-328X(00)93325-4

[3] Arnedillosánchez, I. (2007). Mobile learning, Multimedia Systems, 10(4): 286-301.

[4] Wang, Y. S., Wu, M. C., Wang, H. Y. (2009). Investigating the determinants and age and gender differences in the acceptance of mobile learning, British Journal of Educational Technology, 40(1): 92-118. https://doi.org/10.1111/j.1467-8535.2007.00809.x

[5] Wang, M., Shen, R., Novak, D., Pan, X. (2009). The impact of mobile learning on students' learning behaviours and performance: report from a large blended classroom, British Journal of Educational Technology, 40(4): 673-695. https://doi.org/10.1111/j.1467$\underline{8535.2008 .00846 . x}$

[6] Kurosawa, S., Nakayama, H., Kato, N., Jamalipour, A. (2007). Detecting blackhole attack on aodv-based mobile ad hoc networks by dynamic learning method, International Journal of Network Security, 5(3): 338-346. https://doi.org/10.1109/mahss.2005.1542870

[7] Looi, C. K., Seow, P., Zhang, B. H., So, H. J., Chen, W., Wong, L. H. (2010). Leveraging mobile technology for sustainable seamless learning: a research agenda, British Journal of Educational Technology, 41(2): 154-169.

https://doi.org/10.1111/j.1467-8535.2008.00912.x 
Paper-College English Teaching Status and Individualized Teaching Design in The Context of Mobile ...

[8] Henderson, C. R. (1988). Theoretical basis and computational methods for a number of different animal models, Journal of Dairy Science, 71(2): 1-16.

https://doi.org/10.1016/S0022-0302(88)79974-9

[9] Krause, A., Smailagic, A., Siewiorek, D. P. (2005). Context-aware mobile computing: learning context- dependent personal preferences from a wearable sensor array, IEEE Transactions on Mobile Computing, 5(2): 113-127. https://doi.org/10.1109/TMC.2006.18

[10] Huang, R. T., Jang, S. J., Machtmes, K., Deggs, D. (2012). Investigating the roles of perceived playfulness, resistance to change and self-management of learning in mobile English learning outcome, British Journal of Educational Technology, 43(6): 1004-1015. https://doi.org/10.1111/j.1467-8535.2011.01239.x

[11] Che, P. C., Lin, H. Y., Jang, H. C., Lien, Y. N., Tsai, T. C. (2011). A study of English mobile learning applications at national Chengchi university, International Journal of Distance Education Technologies, 7(4): 38-60. https://doi.org/10.4018/jdet.2009062403

[12] Zhang, S. (2016). Mobile English learning: an empirical study on an app, English fun dubbing, International Journal of Emerging Technologies in Learning, 11(12): 4-4. https://doi.org/10.3991/ijet.v11i12.6314

[13] Cavus, N., Ibrahim, D. (2017). Learning english using children's stories in mobile devices, British Journal of Educational Technology, 48(2). https://doi.org/10.1111/bjet.12427

[14] Elaish, M. M., Shuib, L., Ghani, N. A., Yadegaridehkordi, E., Alaa, M. (2017). Mobile learning for english language acquisition: taxonomy, challenges, and recommendations, IEEE Access, (99): 1-1. https://doi.org/10.1109/ACCESS.2017.2749541

[15] Neelapu, R., Devi, G.L., Rao, K.S. (2018). Deep learning based conventional neural network architecture for medical image classification. Traitement du Signal, 35(2): 169-182. https://doi.org/ 10.3166/TS.35.169-182

[16] Lassandro, P., Zonno, M. (2018). A work-related learning project for energy efficiency evaluation and indoor comfort of school buildings. Ingénierie des Systèmes d'Information, 23(5): 7-27. https://doi.org/10.3166/ISI.23.5.7-27

[17] Liu, G. Z., Chen, J. Y., Hwang, G. J. (2017). Mobile-based collaborative learning in the fitness center: a case study on the development of english listening comprehension with a context-aware application, British Journal of Educational Technology. 49(2): 305-320. https://doi.org/10.1111/bjet.12581

[18] Pandey, M., Litoriya, R., Pandey, P. (2018). Mobile APP development based on agility function. Ingénierie des Systèmes d'Information, 23(6): 19-44.

https://doi.org/10.3166/ISI.23.6.19-44

[19] Saraydaryan, J., Jumel, F., Simonin, O. (2018). Dynamic multi-Agent patrolling: Robotic application for service delivery to mobile people. Revue d'Intelligence Artificielle, 31(4): 379-400. https://doi.org/10.3166/RIA.31.379-400

[20] Yang, J. J., Yuan, Y. L., Zhang, X., Shao, L. F., Gong, L. H., Mi, J., Xu, T. (2018). A deep learning-based image recognition algorithm for fecal shape of domestic rabbits. Revue d'Intelligence Artificielle, 32(S1): 67-78. https://doi.org/ 10.3166/RIA.32.S1.67-78

[21] Jian, C. F., Lu, T., Xiang, X. Y., Zhang, M. Y. (2018). An improved mixed gaussian-based background modelling method for fast gesture segmentation of mobile terminals, Traitement du Signal, 35(3-4): 243-252. https://doi.org/ 10.3166/TS.35.243-252

[22] Halber, A., Chakravarty, D. (2018). Investigation of wireless tracking performance in the tunnel-like environment with particle filter, Mathematical Modelling of Engineering Problems, 5(2): 93-101. https://doi.org/10.18280/mmep.050206 


\section{$7 \quad$ Authors}

Yuan Zhang is the Vice Director of College English Department, Jingdezhen Ceramic Institute (JCI), Jiangxi, China. She received the Master degree of Translation from Xi'an International University in 2014, and BA of English Literature and Linguistics from JiLin University in 2005. She works also as a lecturer in the School of International Studies of JCI for over ten years, and has rich experience in teaching English.

Lu Zuo is a lecturer in the Henan University of Chinese Medicine. She received the Master degree of English Literature and Linguistics from Jilin University in 2007, and B.A. of English Literature and Linguistics from Jilin University in 2005. She works in Henan University of Chinese Medicine for over ten years, and has rich experience in teaching English.

Article submitted 2019-04-19. Resubmitted 2019-06-05. Final acceptance 2019-06-07. Final version published as submitted by the authors. 